\title{
Crested Wheatgrass Defoliation Intensity and Season on Medusahead Invasion
}

\author{
Roger L. Sheley, ${ }^{1}$ Brett S. Bingham, ${ }^{2}$ and Tony J. Svejcar ${ }^{3}$ \\ Authors are ${ }^{1}$ Weed Ecologist, ${ }^{2}$ Range Technician and ${ }^{3}$ Rangeland Scientist, United States Department of Agriculture, Agricultural Research Service, \\ 67826-A Hwy 205, Burns, OR 97720, USA.
}

\begin{abstract}
The objective of this study was to determine the effects of crested wheatgrass (Agropyron cristatum [L.] Gaertn.) defoliation intensity and timing on medusahead density and biomass. We hypothesized that crested wheatgrass defoliation greater than $60 \%$ during the spring would provide maximum medusahead (Taeniatherum caput-medsae [L.] Nevski subsp. asperum [Simk.] Melderis; taxonomy from US Department of Agriculture) density and biomass. Eighteen treatments (six defoliation levels, three seasons of defoliation) were applied to $2-\mathrm{m}^{2}$ plots in a randomized complete block design on two sites with varying clay content. Blocks were replicated five times at each site. Plants were clipped in 2004 and 2005. Crested wheatgrass was hand clipped to defoliation levels of $0 \%, 20 \%, 40 \%, 60 \%, 80 \%$, and $100 \%$ in the spring, summer, or fall. Density of crested wheatgrass and medusahead was sampled in June 2005 and 2006, but their biomass was harvested only in 2006. Data were analyzed with least square means analysis of variance. Over the two seasons, site had much more of an impact on medusahead invasion than either defoliation intensity or timing of defoliation. The results support previous suggestions that clayey soils favor medusahead and that perennial grasses with high biomass can resist this invasive species. On the clayey site where medusahead did persist, fall defoliation of crested wheatgrass reduced the density of this invasive species by $50 \%$ or more compared to spring defoliation. Given the developmental pattern of medusahead, the goal of any management program should be to maximize resource use by the desirable species during April to late July.
\end{abstract}

\section{Resumen}

El objetivo de este estudio fue determinar los efectos de la intensidad de defoliación del triguillo crestado (Agropyron cristatum [L.] Gaertn.) y la estacionalidad en la densidad y biomasa de la cabeza de medusa. Nuestras hipótesis fue que una defoliación del triguillo crestado superior al $60 \%$ durante la primavera proporcionaría máxima densidad y biomasa de la cabeza de medusa (Taeniatherum caput-medsae [L.] Nevski subsp. asperum [Simk.] Melderis). Dieciocho tratamientos (seis niveles de defoliación, tres estaciones de defoliación) se aplicaron a parcelas de $2 \mathrm{~m}^{2}$ en un diseño de bloques completamente al azar, en dos sitios con diferente contenido de arcilla. Los bloques fueron replicados cinco veces en cada sitio. Las plantas se podaron en los años 2004 y 2005. El triguillo crestado fue podado manualmente a niveles de defoliación de $0 \%, 20 \%, 40 \%, 60 \%, 80 \%$, y $100 \%$ en la primavera, verano y otoño. La densidad del triguillo crestado y de la cabeza de medusa fue muestreada en junio del 2005 y 2006, mientras que su biomasa fue recolectada sólo en el 2006. Los datos fueron evaluados con un análisis de varianza de cuadrados mínimos. Durante las dos temporadas, el sitio tuvo mucho más impacto en la invasión de la cabeza de medusa que la intensidad o la temporada de defoliación. Los resultados coinciden con sugerencias anteriores de que suelos arcillosos favorecen las cabezas de medusa y que pastos perennes con alta biomasa y puedan resistir esta especie invasora. En el sitio arcilloso donde la cabeza de medusa persistió, la defoliación de otoño del triguillo crestado redujo la densidad de esta especie invasora en $50 \%$ o más comparada a la defoliación de primavera. Dado el patrón de desarrollo de la cabeza de medusa, el objetivo de cualquier programa de manejo debe ser maximizar el uso de los recursos por las especies deseables entre abril y finales de julio.

Key Words: annual grasses, grazing management, invasive species, weed prevention

\section{INTRODUCTION}

Throughout the Great Basin and surrounding ecosystems, a major factor affecting rangeland resources, fires, and watershed functioning is invasion by the winter annual grass, medusahead (Taeniatherum caput-medsae [L.] Nevski subsp. asperum [Simk.] Melderis; taxonomy from US Department of Agriculture; Miller et al. 1999). This invasive species was introduced in southeastern Oregon in 1884 (Turner et al. 1963). It currently infests several million hectares throughout the Pacific Northwest, California, and Nevada (Miller et al. 1999). Medusahead

Correspondence: Roger L. Sheley, United States Dept of Agriculture, Agricultural Research Service, 67826-A Hwy 205, Burns, OR 97720, USA. Email: roger.sheley@oregonstate.edu

Manuscript received 22 June 2007; manuscript accepted 5 December 2007. occurs in areas receiving 250-1000 mm of annual precipitation (Major et al. 1960). This annual grass has invaded over 2.5 million ha throughout the western United States, and continues to spread at a rapid rate (Miller 1996).

Within the sagebrush steppe, medusahead aggressively displaces perennial grasses by preempting resources, and frequent fires destroy the shrub portion of the plant community (Young 1992). Thus, fire facilitates the conversion of rangeland from a perennial-dominated to an annual-dominated system. Medusahead-dominated sites have $50 \%$ to $80 \%$ less grazing capacity than the original native plant community (Hironaka 1961). Most ecologists believe that medusahead reduces plant and animal diversity and richness, reduces suitable habitat for wildlife, accelerates erosion, and alters nutrient cycles, hydrologic cycles, and energy flow (Olson 1999). 
In arid environments, medusahead commonly occupies clay soils in arid environments that maintain soil moisture late into the growing season (George 1992; Miller 1996). Managers believe this invasive species is becoming increasingly common on clay loam and loam soils. In many cases, medusahead invasion occurs after prolonged domination by cheatgrass (Bromus tectorum L.; Bovey et al. 1961). However, it might be more competitive and persistent on clay soils even though it has the capacity to encroach into native shrub-steppe plant communities on loam soils (Miller 1996). Medusahead has a short life span and high seed production, typical of a ruderal species (Grime 1979). It invades disturbed areas, and in the absence of competition, medusahead demonstrates geometric population growth (Goldberg et al. 2001). Disturbance can increase resource availability (Young and Evans 1976) and with medusahead's high seed production, litter accrual, fall germination, rapid growth rate, and ability to create a selfperpetuating environment, it can effectively dominate and displace desirable species (George 1992). With its aggressive characteristics, medusahead often develops dense monocultures.

Timing, intensity, and frequency of defoliation affect the competitive interactions between invasive species and perennial grasses, and thus influence the ability of a perennial grass to withstand invasive species invasion (Maschinski and Whitham 1989; Briske 1991). An appropriate combination of timing, intensity, and frequency of grazing should allow desired species to remain competitive with invasive species. On seasonallygrazed rangeland, invasive species-free, moderate defoliation and alternating grazing seasons maintain desirable species and constitute proper grazing management (Heitschmidt and Stuth 1991). On land dominated by invasive species, only higher defoliation levels $(>60 \%)$ of crested wheatgrass (Agropyron cristatum [L.] Gaertn.) and bluebunch wheatgrass (Pseudoroegneria spicata [Pursh] A. Löve subsp. spicata) defoliation increased diffuse knapweed density and biomass, indicating that light $(1 \%-30 \%)$ or moderate $(30 \%-60 \%)$ defoliation would not necessarily accelerate invasion by this invasive species (Sheley et al. 1997). Little is known about the effects of defoliation on medusahead establishment in stands of perennial grasses.

Developing strategies to minimize invasive species plant invasion requires understanding the relationship between intensity, frequency, and season of grass defoliation on the establishment and growth of medusahead. The objective of this study was to determine the effects of crested wheatgrass defoliation intensity and timing on medusahead density and biomass. We hypothesized that crested wheatgrass defoliation greater than $60 \%$ during the spring would provide maximum medusahead density and biomass. Crested wheatgrass was used in this study because it has been seeded extensively in the West, and it is often used to revegetate medusahead-dominated rangeland (Miller et al. 1999).

\section{MATERIALS AND METHODS}

\section{Study Sites}

This study was conducted from 2004 to 2006 on two sites. Both sites were within the Wyoming big sage/bluebunch wheatgrass community types of eastern Oregon (Franklin and Dyrness
Table 1. Environmental conditions near both study sites monitored daily.

\begin{tabular}{|c|c|c|c|c|c|c|}
\hline \multirow[b]{2}{*}{ Month } & \multirow{2}{*}{$\begin{array}{c}\text { Total } \\
\text { precipitation } \\
(\mathrm{mm})\end{array}$} & \multicolumn{2}{|c|}{ Wind $\left(\mathrm{km} \cdot \mathrm{hr}^{-1}\right)$} & \multicolumn{3}{|c|}{ Temperature $\left({ }^{\circ} \mathrm{C}\right)$} \\
\hline & & Average & Max. & Max. & Min. & Average \\
\hline January 2004 & 17.8 & 14 & 100 & 7.2 & -14.4 & 2.9 \\
\hline February & 19.6 & 13 & 71 & 6.1 & -12.8 & 2.7 \\
\hline March & 8.9 & 15 & 84 & 21.1 & -6.1 & 5.2 \\
\hline April & 11.7 & 15 & 76 & 22.8 & -5.6 & 7.2 \\
\hline May & 28.7 & 14 & 61 & 23.9 & -1.1 & 9.5 \\
\hline June & 22.1 & 13 & 64 & 30.6 & 0.0 & 15.7 \\
\hline July & 1.3 & 12 & 68 & 32.8 & 4.4 & 20.9 \\
\hline August & 26.2 & 12 & 82 & 33.3 & 5.0 & 19.5 \\
\hline September & 5.1 & 12 & 61 & 26.7 & 0.0 & 13.6 \\
\hline October & 57.7 & 13 & 64 & 23.3 & -4.4 & 7.0 \\
\hline November & 10.7 & 11 & 53 & 14.4 & -10.0 & 1.1 \\
\hline December & 40.4 & 13 & 90 & 10.0 & -8.9 & -0.6 \\
\hline January 2005 & 2.0 & 11 & 76 & 13.3 & -12.2 & -1.2 \\
\hline February & 9.9 & 11 & 43 & 11.1 & -9.4 & -0.3 \\
\hline March & 42.9 & 14 & 85 & 18.9 & -6.1 & 3.2 \\
\hline April & 70.9 & 13 & 60 & 18.3 & -5.6 & 4.1 \\
\hline May & 108.7 & 13 & 55 & 23.3 & -1.1 & 9.7 \\
\hline June & 18.0 & 13 & 69 & 27.8 & -1.1 & 12.3 \\
\hline July & 18.5 & 12 & 87 & 34.4 & 8.3 & 21.3 \\
\hline August & 1.5 & 12 & 61 & 35.0 & 3.3 & 21.0 \\
\hline September & 31.8 & 11 & 64 & 30.0 & 0.0 & 14.3 \\
\hline October & 65.3 & 11 & 61 & 21.7 & -1.7 & 8.3 \\
\hline November & 23.6 & 13 & 68 & 15.6 & -8.9 & 1.0 \\
\hline December & 106.9 & 14 & 77 & 7.2 & -15.6 & -2.8 \\
\hline January 2006 & 29.7 & 15 & 84 & 7.2 & -9.4 & -1.9 \\
\hline February & 19.6 & 14 & 74 & 10.6 & -16.1 & -2.1 \\
\hline March & 42.7 & 14 & 77 & 11.1 & -10.6 & -0.8 \\
\hline April & 53.8 & 14 & 72 & 22.2 & -6.1 & 5.0 \\
\hline May & 32.0 & 13 & 64 & 29.4 & -4.4 & 11.4 \\
\hline June & 23.9 & 12 & 79 & 32.2 & 5.6 & 16.4 \\
\hline July & 2.0 & 12 & 60 & 36.7 & 7.2 & 23.8 \\
\hline
\end{tabular}

1988). Site 1 was located near Venator, Oregon on the Coleman Creek Ranch (lat 43 $33^{\prime} 49.823^{\prime \prime} \mathrm{N}$, long $\left.118^{\circ} 12^{\prime} 42.730^{\prime \prime} \mathrm{W}\right)$, and site 2 was located near the south end of Warm Springs Reservoir (lat $43^{\circ} 26^{\prime} 15.364^{\prime \prime} \mathrm{N}$, long $118^{\circ} 17^{\prime} 48.053^{\prime \prime} \mathrm{W}$ ) near Riverside, Oregon. This habitat, especially with clay soils, is susceptible to invasion by medusahead (Miller et al. 1999). These sites did not have any medusahead plants at the initiation of the study, but the invasive species dominates similar, adjacent sites in the area.

Soils at Coleman Creek are a Mahoon (fine, monotmorillonitic, Aridic Palexerolls)-Brezniak (clayey, montmorillonitic, mesci Lithic Argixerolls)-Longcreek (Clayey-skeletal, montmorillonitic, mesic Lithic Argixerolls) complex. These are very shallow, clayey soils with a claypan about $30 \mathrm{~cm}$ below the surface. Soils at Warm Springs are a Poall-Gumble complex. Poall consists of fine montorillonitic, mesic Xeric Paleargids. Gumble is clayey, montmorillonitic, mesic, shallow Xeric Haplargids. These sites were chosen because they varied in the important characteristic of soil clay content and texture. Both sites are about $1050 \mathrm{~m}$ in elevation and are nearly level.

Environmental conditions were monitored daily at a weather station within $6 \mathrm{~km}$ of both sites within the same community 
type (Table 1). Precipitation for the first year (2004) of the study was $250 \mathrm{~mm}$ with most of the precipitation falling in October through December. In the second year (2005), precipitation was $500 \mathrm{~mm}$ with high amounts in both the spring and fall. During January to July of 2006 the area received area received $93 \mathrm{~mm}$ of precipitation.

Coleman Creek was seeded to crested wheatgrass in 1962, and Warm Springs was seeded in 1981. Since the seeding, Coleman Creek has been grazed by cattle from April to midMay. In about one-half of the years, this area was grazed again in July and early August. It was not grazed at all in 1986, 1987, 1988, and 1991. Average utilization level for the $14 \mathrm{yr}$ that data were collected was $45 \%(\mathrm{SE}=24)$. At Warm Springs, crested wheatgrass was grazed from mid-May to mid-July. It was not grazed in 1991 and was grazed in July and again in mid-October in 1992. Average utilization level for the $15 \mathrm{yr}$ that data were collected was $52 \%(\mathrm{SE}=15)$.

\section{Treatments/Design}

Eighteen treatments (six defoliation levels, three seasons of defoliation) were applied to $2-\mathrm{m}^{2}$ plots in a randomized complete block design. Blocks were replicated five times at each site. Plants were clipped in 2004 and 2005. Crested wheatgrass was hand clipped by weight to defoliation levels of $0 \%, 20 \%, 40 \%, 60 \%, 80 \%$, and $100 \%$ in the spring, summer, or fall. Spring clipping occurred when crested wheatgrass was in the boot growth stage, which was during the first 2 wk of May. Summer clipping occurred at peak standing crop, which was mid-June. Fall clipping occurred during the late-season dormant period for crested wheatgrass. This clipping occurred mid-September. During the summer of 2004, medusahead seeds were collected from within $20 \mathrm{~km}$ of the study sites. In October of 2004, 3000 medusahead seeds $\cdot \mathrm{m}^{-2}$ were uniformly spread across each plot.

\section{Sampling}

Density was sampled in 2005 and 2006 by counting the number of medusahead plants and crested wheatgrass tillers in three randomly located $2 \mathrm{dm} \times 5 \mathrm{dm}$ frames in each plot. On 23 June 2006, the aboveground biomass of crested wheatgrass and medusahead was harvested from each frame, dried at $60^{\circ} \mathrm{C}$ for $48 \mathrm{hr}$ and weighed.

\section{Data Analysis}

Data were first analyzed using multiple linear regression (least squares) models using defoliation level and season as independent variables. Scatterplots of the residual versus the standardized predicted values indicated that the data did not fit a linear model. Therefore, all data were analyzed with least square means analysis of variance (ANOVA). For density, ANOVA was conducted as a split-split-plot in time using Proc Mixed software (SAS Institute Inc. 2004). Rep (site) was used as the error term for site. Defoliation level by season by rep (site) was used as the error term for defoliation level and season of defoliation within site. Year by rep (site) was used as the error term for testing year and year by site. The residual error was used for other interactions with year. Because biomass was only collected in 2006, year was not included in the ANOVA model for biomass. Standard errors of the means are presented. The $P$ values from F-tests, means, and standard errors are presented. Data presented are averaged over factors that were not significant or did not interact.

\section{RESULTS}

\section{Biomass Removed}

In 2004, the amount of biomass removed was similar at both sites during each season of defoliation (Fig. 1). Except for the summer of 2004 at Coleman Creek, the clipping treatments appeared to provide a continuous increase in biomass removed, but the amount of biomass removed did not always significantly differ from the adjacent defoliation level. In the summer at Coleman Creek, defoliation levels targeted to receive $60 \%$, $80 \%$, or $100 \%$ crested wheatgrass removal, in fact, received the same clipping intensity. In 2005, across defoliation treatments, Coleman Creek yielded less crested wheatgrass biomass when clipped in the spring or fall than in 2004 $(P=0.001)$. At Warm Springs, crested wheatgrass removed was higher in 2005 than in 2004 across all defoliation intensities $(P=0.001)$. However, the amount of biomass removed in the spring of 2004 was the same as that removed in the spring of 2005 at Warm Springs $(P=0.120)$.

\section{Crested Wheatgrass and Medusahead, 2005}

In 2005, the only factor that affected crested wheatgrass or medusahead density was site (Table 2). At Coleman Creek, crested wheatgrass produced 129 tillers $\cdot \mathrm{m}^{-2}(\mathrm{SE}=18.3)$, whereas it produced 228 tillers $\cdot \mathrm{m}^{-2}(\mathrm{SE}=18.3)$ at Warm Springs when averaged across all other treatments that year. Medusahead produced 125 plants $\cdot \mathrm{m}^{-2}(\mathrm{SE}=7.9)$ at Coleman Creek and only 20 plants $\cdot \mathrm{m}^{-2}(\mathrm{SE}=7.9)$ at Warm Springs in 2005.

\section{Crested Wheatgrass and Medusahead, 2006}

Crested wheatgrass density and biomass depended upon site in 2006 (Tables 2 and 3). This grass produced 122 tillers $\cdot \mathrm{m}^{-2}$ $(\mathrm{SE}=25)$ at Coleman Creek and 366 tillers $\cdot \mathrm{m}^{-2}(\mathrm{SE}=25)$ at Warm Springs when averaged across all treatments. Crested wheatgrass biomass followed a similar pattern that year. It produced $25 \mathrm{~g} \cdot \mathrm{m}^{-2}(\mathrm{SE}=4.0)$ at Coleman Creek and 47 $\mathrm{g} \cdot \mathrm{m}^{-2}(\mathrm{SE}=4.0)$ at Warm Spring when averaged across all treatments.

Medusahead density and biomass depended upon site and interacted with season of defoliation, but not defoliation intensity, in 2006 (Table 3). At Coleman Creek, defoliating crested wheatgrass in either the spring or summer yielded about twice the number of medusahead plants than defoliating the bunchgrass in the fall (Fig. 2). By 2006, there were no detectable medusahead plants at Warm Springs.

Clipping crested wheatgrass in the summer yielded the highest medusahead biomass at Coleman Creek, which was about $7 \mathrm{~g} \cdot \mathrm{m}^{-2}$ (Fig. 3). Spring crested wheatgrass defoliation reduced the medusahead yield to about $5 \mathrm{~g} \cdot \mathrm{m}^{-2}$, whereas defoliation in the fall produced about $3 \mathrm{~g} \cdot \mathrm{m}^{-2}$ of this invasive species. Because there were no medusahead plants at Warm Springs, there was no biomass of this invasive species in 2006. 

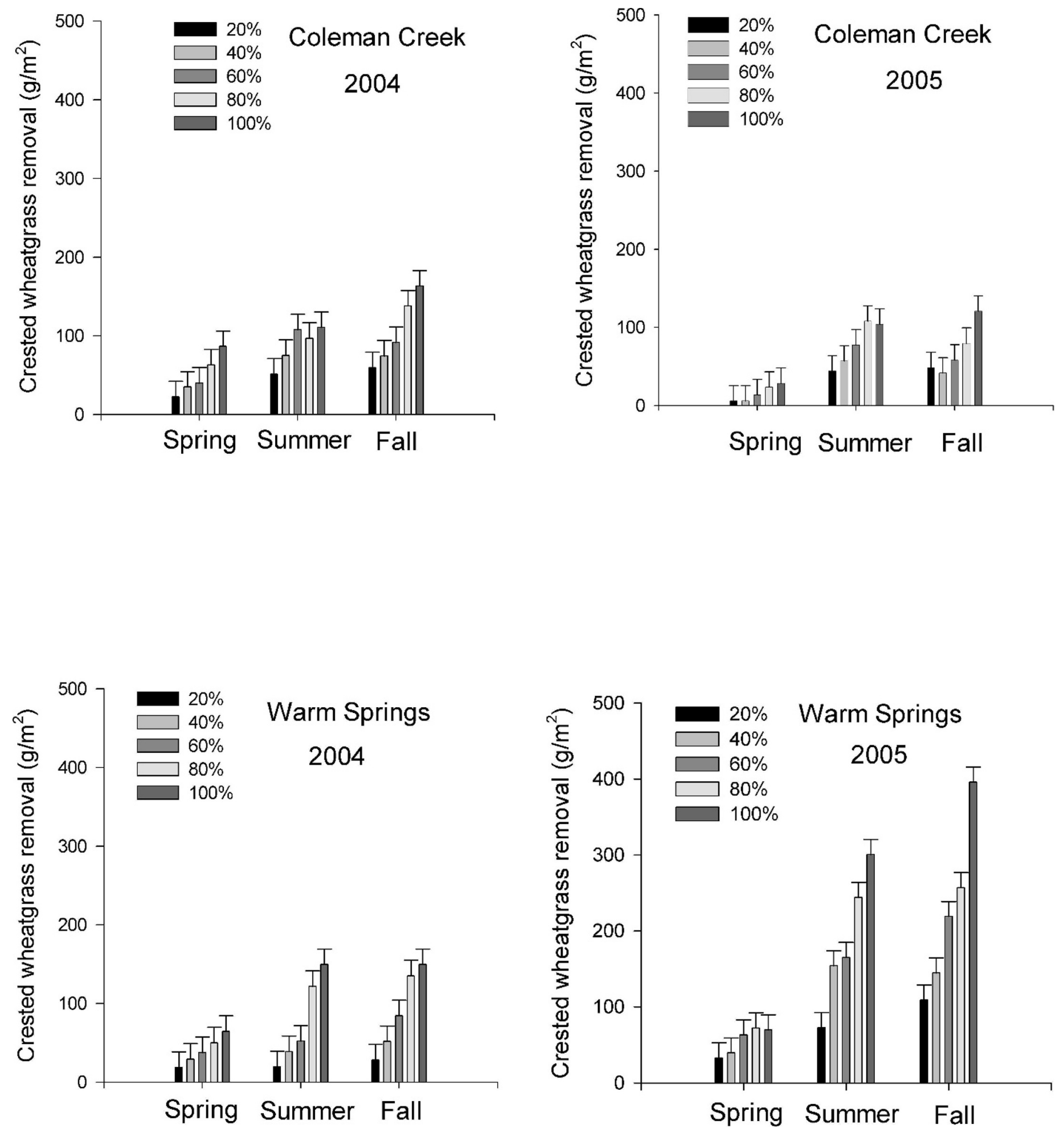

Figure 1. Biomass of crested wheatgrass removed from plots at Coleman Creek and Warm Spring in 2004 and 2005. Bars represent 1 SE.

\section{DISCUSSION}

Over the two growing seasons of this study, site had much more impact on medusahead persistence than did either defoliation intensity or timing. The results support previous suggestions that harsh, clayey soil favors medusahead (Miller et al. 1999). It also indicates that invasive annual grasses are favored by low biomass of perennial grasses (Lulow 2006). On the site where medusahead did persist, timing of defoliation did influence medusahead density and biomass (Figs. 2 and 3). Fall defoliation of crested wheatgrass reduced density and biomass of medusahead by $50 \%$ or more compared to spring or early summer defoliation. We suspect that fall defoliation was most likely to stimulate leaf area development of crested wheatgrass 
Table 2. P-values from ANOVA of density in 2005.

\begin{tabular}{lrcc}
\hline & df & Crested wheatgrass & Medusahead \\
\hline Def $^{1}$ & 5 & 0.590 & 0.178 \\
Season & 2 & 0.684 & 0.637 \\
Season * def & 10 & 0.487 & 0.147 \\
Site & 1 & 0.005 & 0.001 \\
Site * def & 5 & 0.864 & 0.114 \\
Site $^{*}$ Season & 2 & 0.994 & 0.338 \\
Site $^{*}$ def * season & 10 & 0.446 & 0.235 \\
\hline
\end{tabular}

${ }^{1}$ Def indicates defoliation.

the following spring. Given the life-history pattern of medusahead, the goal of any management program should be to maximize resource use by desirable species during April and late July.

Defoliation intensity is generally considered a major factor determining the competitive relationship between desired plants and invasive species (Briske 1991). In Washington, clipping a bluebunch wheatgrass (Pseudoroegneria spicata [Pursh.] A. Löve)/needle-and-thread (Stipa comata Trin. \& Rupr.) community greater than $60 \%$ enhanced diffuse knapweed (Centaurea diffusa Lam.) establishment (Sheley et al. 1997). In that study, clipped crested wheatgrass recovered more rapidly from defoliation intensities greater than $60 \%$ and was slightly more effective in limiting invasion at more severe defoliation levels than the native grasses. Similarly, 60\% defoliation of Idaho fescue (Festuca idhaoensis Elmer) increased spotted knapweed density (Centaurea stoebe L. subsp. micranthus [Gugler] Hayek) in Montana. In the current study, we did not detect a response by medusahead to crested wheatgrass defoliation intensity at either site $(P=0.150)$, regardless of the season of defoliation. One explanation is that our clipping levels were variable enough to mask any differences in the response by medusahead to crested wheatgrass defoliation intensity (see Fig. 1).

A second explanation is that crested wheatgrass is widely recognized as a grazing-tolerant species because of its ability to regrow after defoliation (Cook et al. 1958; Caldwell et al. 1981). Cook et al. (1958) found that the number of flowering culms a single year after defoliation was similar whether crested wheatgrass plants were clipped to a 2.5 - or 7.5 -cm stubble on plots that received supplemental water. Crested wheatgrass invests nitrogen and carbohydrates into new tiller growth, rather than root growth, after defoliation (Caldwell et al.

Table 3. P-values from ANOVA of density and biomass in 2006.

\begin{tabular}{|c|c|c|c|c|c|}
\hline & \multirow[b]{2}{*}{ df } & \multicolumn{2}{|c|}{ Crested wheatgrass } & \multicolumn{2}{|c|}{ Medusahead } \\
\hline & & Density & Biomass & Density & Biomass \\
\hline Def $^{1}$ & 5 & 0.650 & 0.155 & 0.205 & 0.306 \\
\hline Season & 2 & 0.770 & 0.287 & 0.015 & 0.012 \\
\hline Season * def & 10 & 0.923 & 0.828 & 0.664 & 0.455 \\
\hline Site & 1 & 0.001 & 0.001 & 0.001 & 0.001 \\
\hline Site * def & 5 & 0.879 & 0.875 & 0.158 & 0.199 \\
\hline Site $^{\star}$ season & 2 & 0.996 & 0.871 & 0.016 & 0.012 \\
\hline Site * def * season & 10 & 0.654 & 0.999 & 0.716 & 0.488 \\
\hline
\end{tabular}

${ }^{1}$ Def indicates defoliation.

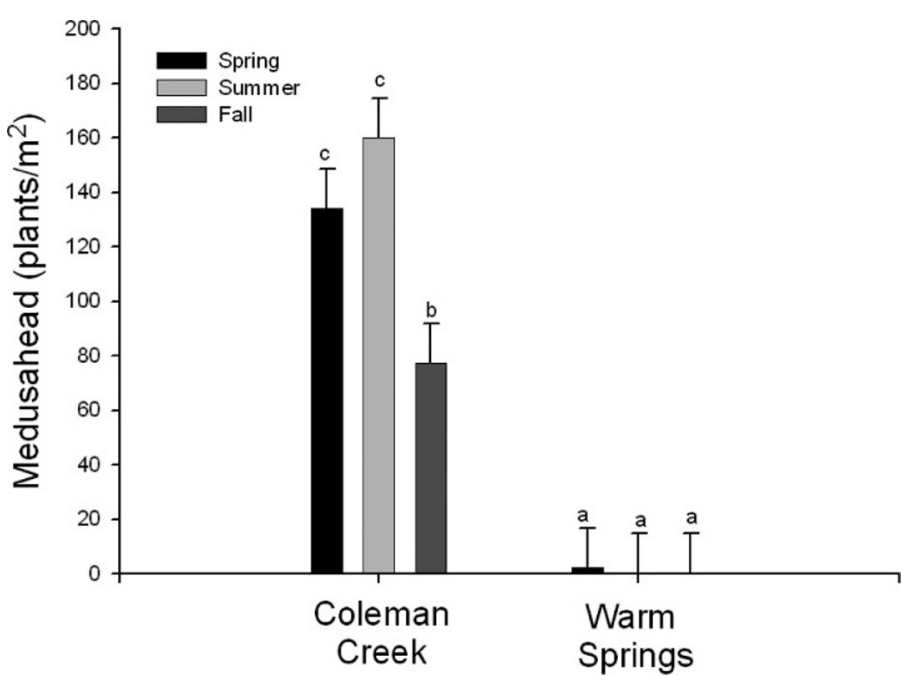

Figure 2. Effect of season of defoliation on medusahead density in 2006. Bars represent 1 SE.

1981). Investing in new tiller growth provides the photosynthetic machinery to promote rapid recovery after severe defoliation. It is possible that the investment in tiller growth allowed crested wheatgrass to fully recover biomass regardless of defoliation intensity over the short term. These results were consistent with those found by Sheley et al. (1997) for crested wheatgrass defoliation intensity.

Crested wheatgrass biomass tended to decrease the year following the first defoliation at Coleman Creek, especially in those plots clipped in the spring. The season of defoliation was more critical to the recovery of crested wheatgrass than the intensity of defoliation at this site. Crested wheatgrass is least tolerant to grazing during the boot growth stage (Blaisdell and Pechanec 1949; Mueggler 1972; Caldwell et al. 1981). Although Hyder and Sneva (1963) did not study defoliation intensity, they also found that clipping crested wheatgrass in the spring (May) depressed total biomass production for the season. There appears to be an ecological risk to allocating resources to new aboveground photosynthetic machinery

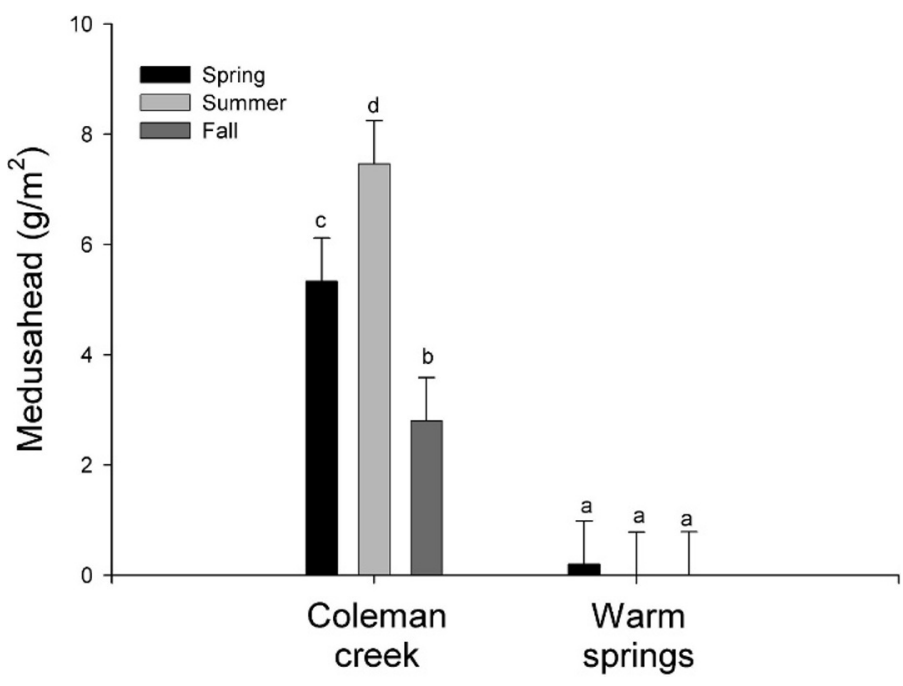

Figure 3. Effect of season of defoliation on medusahead biomass in 2006. Bars represent 1 SE. 
immediately after defoliation if too little soil moisture exists to continue growth long enough to regain root growth as well (Bloom et al. 1985; Gleeson and Fry 1997). We speculate that the heavy clay soils and shallow claypan prevented enough water storage to allow adequate growth for recovery of crested wheatgrass after spring defoliation at Coleman Creek. On the other hand, the deeper soil at Warm Springs probably provided moisture to plants for a longer growing season, allowing crested wheatgrass to fully recover its tiller and root biomass at this site by 2005 .

At Warm Springs, crested wheatgrass increased its total biomass in 2005 after being clipped for the first time (2004) in the summer or fall. When bunchgrasses are not grazed in a single year, standing dead leaves and stems persist, which in turn reduces their likelihood of being grazed in subsequent grazing seasons (Norton and Johnson 1986; Ganskopp et al. 1992). This aspect of grazing behavior is particularly pronounced in crested wheatgrass (Norton et al. 1983; Norton and Johnson 1986). The apical meristem and young leaves of a lead tiller exert hormonal regulation of axillary bud growth that inhibits the development of vegetative tillers (Briske 1991; Murphy and Briske 1992; Briske and Richards 1995). Defoliation can stimulate the tillering process in grass plants by removing apical dominance and increase tiller density and biomass production (Manske 2003).

Aggressive nonindigenous invasive species can invade in the absence of defoliation and/or livestock grazing (Tyser and Key 1988; Sheley et al. 1997). Medusahead has been strongly associated with heavy clay soils. (Miller 1996). In situations where crested wheatgrass alone is incapable of preempting soil resources from invasive species seedlings, invasion occurs (Carpinelli et al. 2004). Medusahead has the ability to continue to acquire soil resources at greater depth and/or low soil matric potentials than even cheatgrass (Bromus tectorum L.) because medusahead roots have thicker cell walls, which allow it to conduct water through very dry soil horizons (Harris 1977). On marginal rangeland sites such as Coleman Creek, where crested wheatgrass biomass production is hindered by poor conditions for growth, medusahead can successfully acquire enough nutrients to become well established. This mechanism for invasion success has been described in relation to defoliation by Jacobs and Sheley (1997) for spotted knapweed. Rangeland dominated by clay soils can be subject to invasion, regardless of grazing management.

On these marginal sites, improper grazing can accelerate invasion. In many cases, increasing the intensity of defoliation and/or the frequency of defoliation within a growing season increases the susceptibility of the plant community to invasion (Jacobs and Sheley 1997, 1999). In the case of medusahead, the season of defoliation appears to be more critical to accelerating invasion than the defoliation level. Medusahead establishment was highest where crested wheatgrass was unable to fully recover its biomass production by the following growing season, a result consistent with other studies (Sheley et al. 1997; Jacobs and Sheley 1997, 1999). Collectively, these studies suggest that grazing management that allows desired species to fully recover their biomass by the next growing season will be most resistant to invasion. However, marginally productive sites will not be completely invasion-resistant, regardless of grazing management.
It is commonly stated that soils with less clay and more silt and sand are more resistant to medusahead invasion (Miller et al 1999). Our data support this, given that Warm Springs, which has deep clayey loam soils, had a medusahead density of 20 plants $\cdot \mathrm{m}^{-2}$ in 2005 , whereas values at Coleman Creek were six times larger. In 2006, after two seasons of defoliation, the only plots left with even a trace of medusahead were those defoliated in the spring at this site (Figs. 2 and 3). It appears that the moisture and nutrient-acquiring mechanisms possessed by medusahead do not confer a major advantage at these soil textures (Harris and Wilson 1970).

\section{MANAGEMENT IMPLICATIONS}

Our study supports the conclusion that on clayey loams and loamy soils, established crested wheatgrass is likely capable of resisting invasion by medusahead if the plants are managed in a manner that allows them to fully regain their biomass production from one grazing season to the next (Harris and Wilson 1970; Sheley et al. 1997). We believe that the response of crested wheatgrass to defoliation, and potentially grazing, and corresponding invasion of medusahead follows a bellshaped curve on these soil textures. Heavy repeated defoliation in the spring prevents crested wheatgrass from fully recovering its biomass production by the following grazing event (Hyder and Sneva 1963) and allows invasion (Sheley et al. 1997). On the other end of the curve, no defoliation allows crested wheatgrass to become old and decadent, and in turn, impedes its ability to rapidly grow to develop a competitive root system in the spring (Norton and Johnson 1986). Our study shows that periodic defoliation of crested wheatgrass is required to maintain enough young, vigorous growth to successfully outcompete medusahead. At one site, defoliating crested wheatgrass in the summer or fall stimulated enough aggressive growth to completely remove all medusahead that had established in the prior year. Without other major disturbances, moderate to heavy grazing intensity applied to crested wheatgrass while alternating the season of use should prevent invasion of medusahead on clay loam soils.

\section{LITERATURE CITED}

Blaisdell, J. P., and J. F. Pechanec. 1949. Effects of herbage removal at various dates and vigor of bluebunch wheatgrass and arrowleaf balsamroot. Ecology 30:298-305.

Bloom, A. J., F. S. Chapin III, and H. A. Mooney. 1985. Resource limitation in plants: and economic analogy. Annual Review of Ecological Systems 16:363-392.

Bovey, R. W., D. Le Tourneau, and L. C. ERickson. 1961. The chemical composition of medusahead and downy brome. Weeds 9:307-311.

BRISKE, D. D. 1991. Developmental morphology and physiology of grasses. In: B. K. Heitschmidt and J. W. Stuth [EDS.]. Grazing management: an ecological perspective. Portland, OR, USA: Timber Press, Inc. p. 85-108.

BRISKE, D. D., AND J. H. Richards. 1995. Plant responses to defoliation: a physiological, morphological and demographic evaluation. In: D. J. Bedunah and R. E. Sosebee [EDS.]. Wildland plants: physiological ecology and developmental morphology. Denver, C0, USA: Society of Range Management. p. $635-710$.

Caldwell, M. M., J. H. Richards, D. A. Johnson, R. S. Nowak, and R. S. Dzurec. 1981. Coping with herbivory: photosynthetic capacity and resource allocation in two semiarid Agropyron bunchgrasses. Oecologia 50:14-24. 
Carpinelli, M. F., R. L. Sheley, and B. D. Maxwell. 2004. Revegetating weed-infested rangeland with niche-differetiated desireable species. Journal of Range Management 57:97-105.

Cook, C. W., L. A. Stoddart, and F. E. Kinsinger. 1958. Responses of crested wheatgrass to various clipping treatments. Ecological Monographs 28:237-272.

Franklin, J. E., and C. T. Dyrness. 1988. Natural vegetation of Oregon and Washington. Corvallis, OR, USA: Oregon State University Press. 427 p.

Ganskopp, D., R. Angel, And J. Rose. 1992. Response of cattle to cured reproductive stems in a caespitose grass. Journal of Range Management 45:401-404.

George, M. R. 1992. Ecology and management of medusahead. Davis, CA, USA: University of California Range Science Report 32. 3 p.

GLEESON, S. K., AND J. FRY. 1997. Root proliferation and marginal patch value. Oikos 79:387-393.

Goldberg, D. E., R. Turkington, L. Olsvig-Whittaker, and A. R. Dyer. 2001. Density dependence in an annual plant community: variation among life history stages. Ecological Monographs 71(3):423-446.

Grime, J. P. 1979. Plant strategies and vegetation processes. Chichester, United Kingdom: Wiley. 222 p.

HaRris, G. A. 1977. Root phenology as a factor of competition among grass seedlings. Journal of Range Management 30:172-177.

HarRIS, G. A., AND A. M. WILson. 1970. Competition for moisture among seedlings of annual and perennial grasses as influenced by root elongation at low temperature. Ecology 41:530-534.

Heitschmidt, R. K., AND J. W. Stuth. 1991. Grazing management: an ecological perspective. Portland, OR, USA: Timber Press, Inc. 259 p.

HiRonaka, M. 1961. The relative rate of root development of cheatgrass and medusahead. Journal of Range Management 14:263-267.

Hyder, D. N., And F. A. Sneva. 1963. Morphological and physiological factors affecting the grazing management of crested wheatgrass. Crop Science 3:267-271.

JaCOBS, J. S., AND R. L. Sheley. 1997. Relationship among Idaho fescue defoliation, soil water, and spotted knapweed emergence and growth. Journal of Range Management 50:258-262.

JaCoBS, J. S., And R. L. Sheley. 1999. Grass defoliation intensity, frequency, and season effects on spotted knapweed invasion. Journal of Range Management 52(6):626-632.

LuLow, M. E. 2006. Invasion by non-native annual grasses: the importance of species biomass, composition, and time among California native grasses of the Central Valley. Restoration Ecology 14:616-626.

Major, J., C. M. McKell, and L. J. BerRy. 1960. Improvement of medusahead infested rangeland. Davis, CA, USA: California Agriculture Experiment Station, Extension Service Leaflet 123. 6 p.
MAnSKE, L. L. 2003. Effects of grazing management treatments on rangeland vegetation. Dickinson, ND, USA: North Dakota State University Dickinson Research Extension Center, Range Research Report DREC 03-3027. 6 p.

Maschinski, J., And T. G. Whitham. 1989. The continuum of plant responses to herbivory: the influence of plant association, nutrient availability, and timing. American Naturalist 134:1-19.

MılleR, H. C. 1996. Demography of medusahead on two soil types: potential for invasion into intact native communities [MS thesis]. Corvallis, OR, USA: Department of Rangeland Resources, Oregon State University. $36 \mathrm{p}$.

Miller, H. C., D. Clausnitzer, and M. M. Borman. 1999. Medusahead. In: R. L. Sheley and J. K. Petroff [EDS.]. Biology and management of noxious weeds. Corvallis, OR, USA: Oregon State University Press. p. 271-281.

Mueggler, W. F. 1972. Influence of competition on the response of bluebunch wheatgrass to clipping. Journal of Range Management 25:88-92.

Murphy, J. S., AND D. D. BrISkE. 1992. Regulation of tillering by apical dominance: chronology, interpretive value, and current perspectives. Journal of Range Management 45:419-429.

Norton, B. E., and P. S. Johnson. 1986. Impact of grazing on crested wheatgrass in relation to plant size. In: K. Johnson [ED.]. Crested wheatgrass: its values, problems and myths. Proceedings of the Crested Wheatgrass Symposium; October 1983. Logan, UT, USA: Utah State University. p. 275-279.

Norton, B. E., P. S. Johnson, and M. K. Owens. 1983. Increasing grazing efficiency on crested wheatgrass. Utah Science 43:110-113.

OLson, B. E. 1999. Grazing weeds. In: R. L. Sheley and J. K. Petroff [Eds.]. Biology and management of noxious weeds. Corvallis, OR, USA: Oregon State University Press. p. 85-96.

SAS InstituTe Inc. 2004. SAS OnlineDoc ${ }^{\circledR}$ 9.1.3. Cary, NC, USA: SAS Institute Inc.

Sheley, R. L., B. E. Olson, and L. L. Larson. 1997. Effect of weed seed rate and grass defoliation level on diffuse knapweed. Journal of Range Management 50:39-43.

Turner, R. B., C. E. Poulton, and W. L. Gould. 1963. Medusahead-a threat to Oregon rangeland. Corvallis, OR, USA: Oregon State University, Agriculture Experiment Station, Special Report 149. 22 p.

TYSER, R. W., AND C. H. KeY. 1988. Spotted knapweed in a natural area fescue grassland: an ecological assessment. Northwest Science 62:151-160.

Young, J. A. 1992. History and use of semiarid plant communities-changes in vegetation. In: S. B. Monsen and S. G. Kitchen [EDS.]. Proceedings of the Symposium On Ecology and Management of Annual Rangelands; 18-22 May 1992; Boise, ID, USA. Ogden, UT, USA: USDA-ARS, General Technical Report INT-GTR-313. p. 5-8.

Young, J. A., And R. A. Evans. 1976. Response of weed populations to human manipulations of the natural environment. Weed Science 24:186-190. 